\title{
Floods and Flood Plains
}

\section{Floods are common and costly natural disasters}

When rivers overflow their banks, or flood, they can cause damage to property and crops. Floods are common and costly natural disasters. In the United States, the average annual cost of flood damage is more than $\$ 2$ billion. Each year about 100 people lose their lives to floods.

Floods usually are local, short-lived events that can happen suddenly, sometimes with little or no warning. They usually are caused by intense storms that produce more runoff than an area can store or a stream can carry within its normal channel. Rivers can also flood when dams fail, when ice jams or landslides temporarily block a channel, or when snow melts rapidly. In a broader sense, normally dry lands can be flooded by high lake levels, by high tides, or by waves driven ashore by strong winds. Small streams, particularly in the Southwest, are subject to flash floods (very rapid increases in runoff), which may last from a few minutes to a few hours. On larger streams, floods usually last from several hours to a few days. A series of storms might keep a river above flood stage (the water level at which a river overflows its banks) for several weeks.

\section{Weather patterns can determine when floods occur}

Floods can occur at any time, but weather patterns have a strong influence on when and where floods happen. Cyclones, or storms that bring moisture inland from the ocean, can cause floods in the winter and early spring in the western United States. Thunderstorms are relatively small but intense storms that can cause flash floods in smaller streams in late summer and fall in the Southwest. Frontal storms form at the front of large, moist air masses moving across the country and can cause floods in the northern and eastern parts of the United States during the winter and spring. Hur-

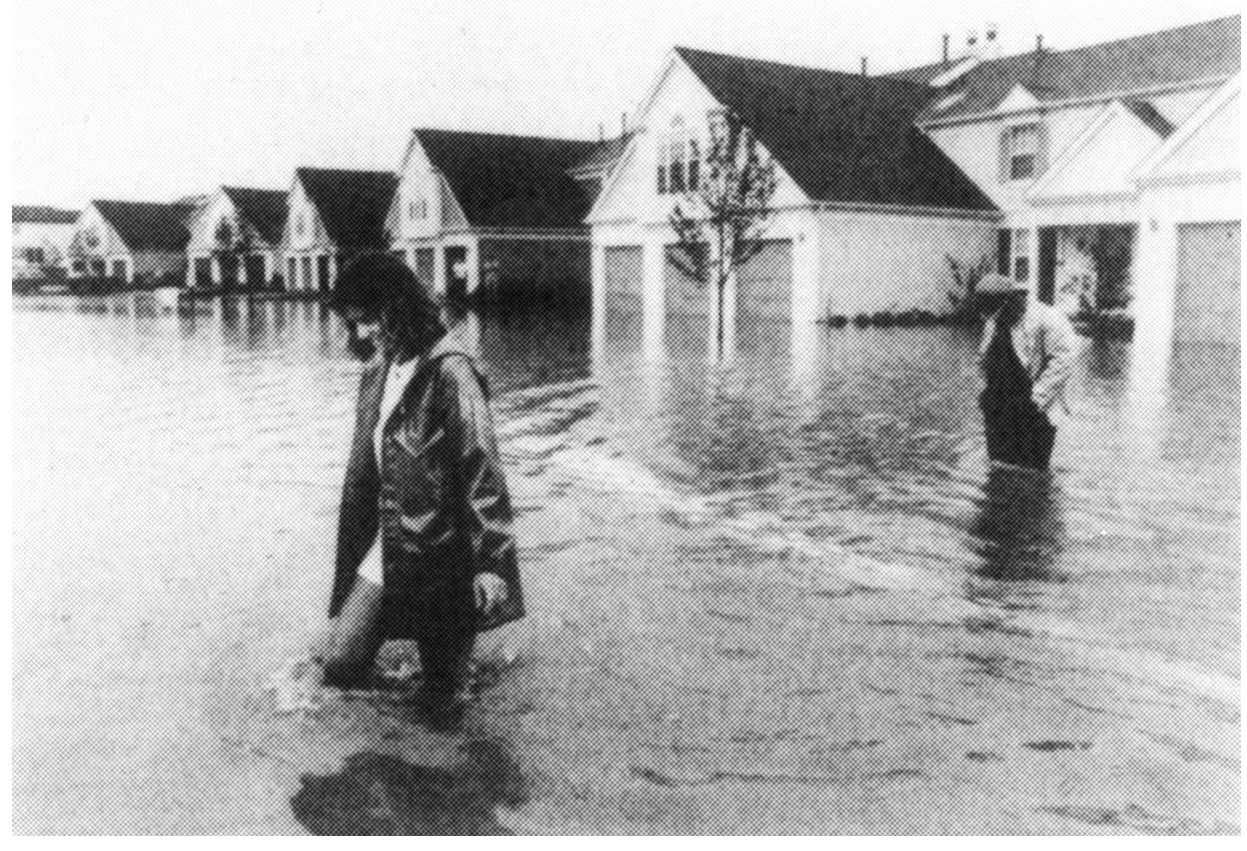

ricanes are intense tropical storms that can cause floods in the Southeast during the late summer and fall.

\section{Very large floods happen very seldom}

The size, or magnitude, of a flood is described by a term called recurrence interval. By studying a long period of flow records for a stream, it is possible to esti-

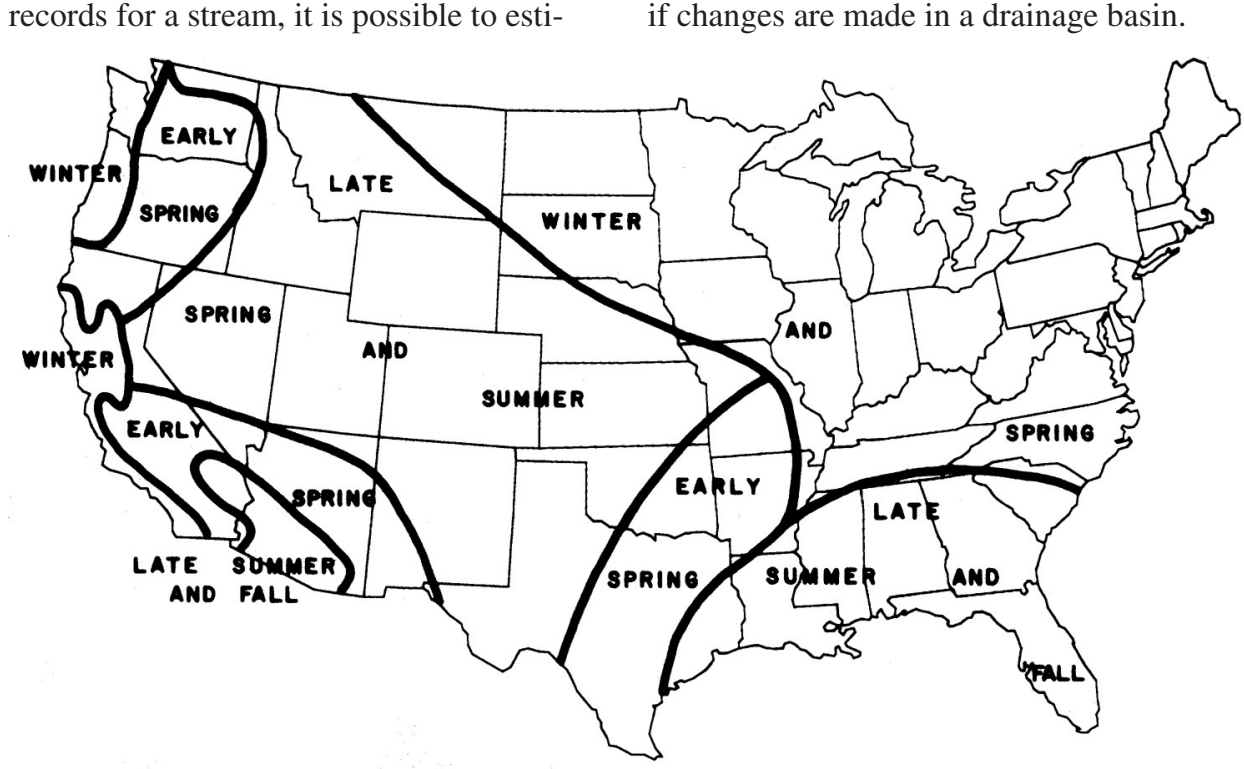
example, have a 5-year recurrence interval (called a 5-year flood). A 5-year flood is one that would occur, on the average, once every 5 years. Although a 100-year flood is expected to happen only once in a century, there is a 1 percent chance that a flood of that size could happen during any year.

The magnitude of floods can be altered if changes are made in a drainage basin. mate the size of a flood that would, for 
Harvesting timber or changing land use from farmland to housing developments can cause the runoff to increase and cause an increase in the magnitude of flooding. Building dams that store water can reduce the magnitude of floods.

\section{Flood plains normally are dry}

Flood plains are lands bordering rivers and streams that normally are dry but are covered with water during floods. Buildings or other structures placed in flood plains can be damaged by floods. They also can change the pattern of water flow and increase flooding and flood damage on adjacent property by blocking the flow of water and increasing the width, depth, or velocity of flood waters.

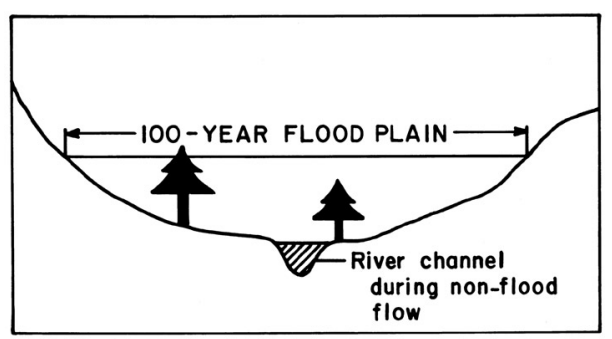

FLOOD PLAINS NORMALLY ARE DRY

\section{Dams and levees can reduce the risk of floods}

Flood-control dams have been built on many streams and rivers to store storm runoff and reduce flooding downstream. Although the same volume of water must eventually move down the river, the peak flow (the largest rate of streamflow during a flood) can be reduced by temporarily storing water and releasing it when river levels have fallen. Levees are artificial river banks built to control the spread of flood waters and to limit the amount of land covered by floods. Levees provide protection from some floods but can be over-topped or eroded away by large floods. For example, levees failed to protect vast areas in the Mississippi and Missouri River valleys during the record-setting floods that occurred in 1993.

\section{For additional information, please contact:}

U.S. Geological Survey

Water Resources Division

12201 Sunrise Valley Dr.

Reston VA 20192

Chief, Office of Surface Water

Telephone: (703) 648-5305 FAX: (703) 648-5722

http://water.usgs.gov/osw/

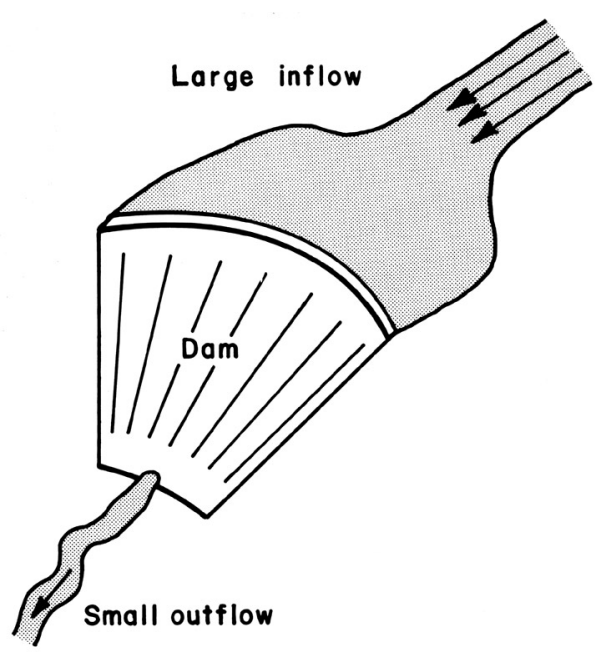

\section{Zoning restrictions limit flood damage}

Flood-plain zoning, which places restrictions on the use of land on flood plains, can reduce the cost of flood damage. Local governments may pass laws that prevent uncontrolled building or development on flood plains to limit flood risks and to protect nearby property. Landowners in areas that adopt local ordinances or laws to limit development on flood plains can purchase flood insurance to help cover the cost of damage from floods.
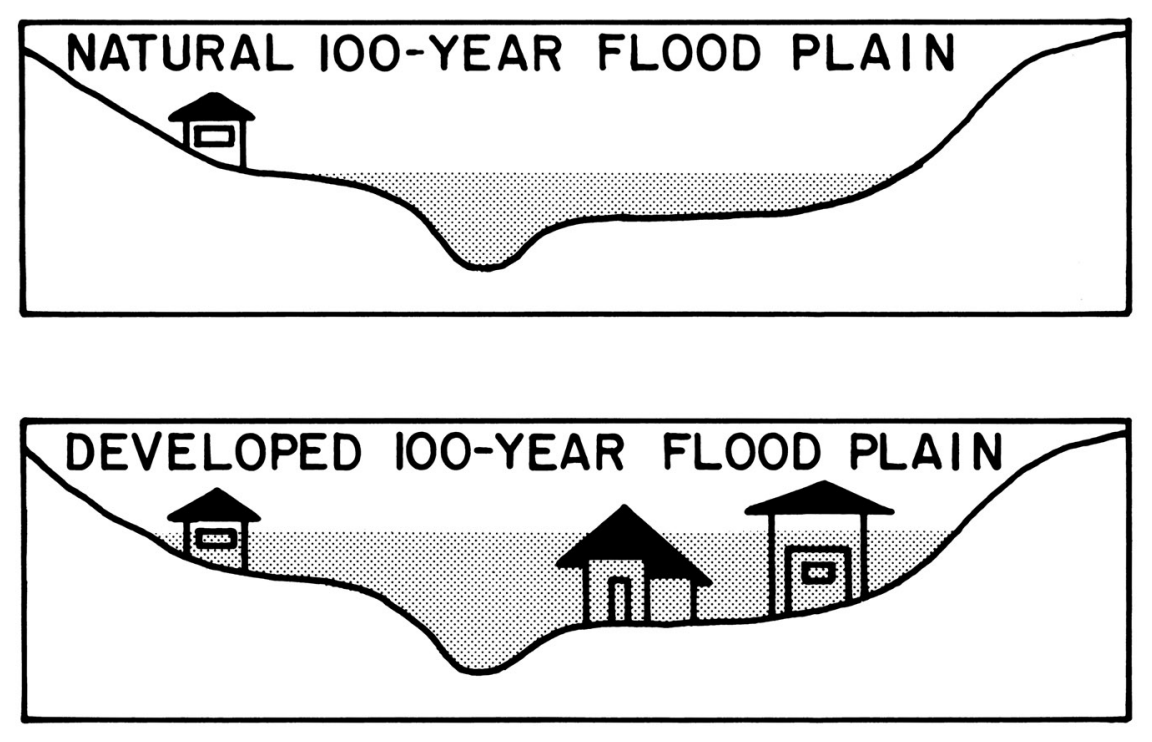

\section{BUILDING ON FLOOD PLAINS INCREASES THE RISK OF FLOOD HAZARDS}

